\title{
Multidimensional Incongruence, Political Disaffection, and Support for Anti-Establishment Parties
}

\author{
November 20, 2019
}

\begin{abstract}
To what extent do representational gaps between parties and voters destabilize party systems and create electoral opportunities for anti-establishment parties on the left and right? In this paper, we use multiple measures of party-partisan incongruence to evaluate whether issue-level incongruence contributes to an increase of political disaffection and anti-establishment politics. For this analysis, we use data from the Chapel Hill Expert Survey (CHES) for party positions and public opinion data from the European Election Study (EES). Our findings indicate that multidimensional incongruence is associated with disaffection at the national and European level, and that disaffected mainstream party voters are in turn more likely to consider voting for anti-establishment challenger parties. This finding suggests that perceived gaps in party-citizen substantive representation have important electoral ramifications across European democracies.
\end{abstract}

\section{Bios}

Ryan Bakker is a Reader in Comparative Politics at the University of Essex. His research interests include political parties, elections, public opinion, and measurement. His research had been published in journals such as the American Journal of Political Science, Journal of Politics, and Political Analysis.

Seth Jolly is an Associate Professor of Political Science at Syracuse University. His research focuses on European party competition, representation, and regionalist movements. His first book on The European Union and the Rise of Regionalist Parties was published by University of Michigan Press in 2015.

Jonathan Polk is an associate professor at the University of Copenhagen and the University of Gothenburg. His research interests include party competition, intra-party politics and representation.

Keywords: European Union, political parties, representation, populism

Word count: 6,531 words (including references, notes, abstract) plus 3 pages of figures/tables (475 words/page), yielding 7,956 total words. 
disaffection | , disə'fekSH(ə)n |

noun. a state or feeling of being dissatisfied with the people in authority and no longer willing to support them (New Oxford American Dictionary).

Research on citizen satisfaction with democracy differentiates between input-oriented, procedural aspects of politics and output-oriented measurements of regime performance (Hobolt 2012; Dahlberg and Holmberg 2014; Strebel, Kübler, and Marcinkowski 2018). Recently, there has been a turn to addressing multidimensional incongruence as an important input factor related to citizen satisfaction with democracy (Stecker and Tausenpfund 2016), suggesting that incongruence between citizens and governments on issues beyond the general left-right dimension decreases satisfaction with democracy across a range of European countries.

In this paper, we build on these studies by examining variation in incongruence levels between mainstream political parties and their voters across a range of issues and dimensions and their relationship to citizen disaffection. ${ }^{1}$ Following Putnam, Pharr, and Dalton (2000, 8), our 'concern is with popular confidence in the performance of representative institutions' and the potential effects if that confidence is broken. Furthermore, we argue that 'democratic disaffection', thought of as an estrangement and distance from politics as a whole, represents something more conceptually extreme and appropriate for many contemporary European polities than does 'democratic dissatisfaction' (Magalhães 2005, 976). Working from basic spatial assumptions about political competition and the interplay between party supply and citizen demand, our expectation is that higher levels of ideological incongruence between voters and their parties (i.e., less agreement between the policy positions of a party and the preferences of its voters on that topic) will be associated with more political disaffection.

We test our expectation on latent variables constructed from a number of items included in the 2014 wave of the European Election Study (EES) (Schmitt et al. 2015) to measure

\footnotetext{
${ }^{1}$ By mainstream, we mean parties belonging to the Conservative, Liberal, Christian Democratic and Socialist party families. By incongruence levels, we mean the absolute distance between the policy position of the mainstream political party (in or out of government) and the self-reported policy positions of citizens that reported voting for that party in the previous national election.
} 
citizen disaffection towards the EU and their national political system. Our primary explanatory variables are a series of party-voter incongruence scales created by combining citizen responses to questions included in the 2014 EES with expert placements of political party positions from the 2014 Chapel Hill Expert Survey (CHES)(Polk et al. 2017) on the same questions. To preview our findings, party-voter incongruence levels are a significant predictor of citizen disaffection across a range of model specifications, even after controlling for a variety of economic and demographic factors. Incongruence between a party and its voters on policy issues beyond general left-right ideology, such as immigration and redistribution, is associated with more disaffection towards the national political system, while EU incongruence has a stronger relationship with EU disaffection. These findings suggest that a multidimensional conception of the representational relationship between citizens and parties is essential for understanding party democracy in European countries that are increasingly embedded in a complex system of multi-level governance (Hooghe and Marks 2003).

We further argue that this political disaffection has consequences for political behaviour, including support for anti-elite parties. As Inglehart (1988, 1214) anticipated, 'relatively low levels of diffuse satisfaction and trust make one more likely to reject the existing political system and support parties of the extreme Right or Left.' In the final section, we show that disaffection is associated with a higher propensity to vote for anti-establishment parties, even for self-reported mainstream party voters, and that disaffection with the European Union is as important as national disaffection for understanding the decision to consider voting for anti-system parties. This finding underlines the relevance of domestic contestation of the European Union (De Vries 2018a; Hobolt 2018), an area in which mainstream political parties have been relatively unresponsive to citizen preferences (Rohrschneider and Whitefield 2016; Hooghe and Marks 2018). In short, mainstream parties' struggle to represent the multidimensional interests of their voters results in increased levels of voter disaffection, which poses challenges to representative party democracy in Europe. 


\section{Incongruence and Citizen Disaffection}

Mainstream parties of all ideological stripes have suffered substantial reductions in their vote share in recent years (Hobolt and Tilley 2016). Following Rohrschneider and Whitefield (2012), we argue that a fundamental problem for today's political parties is the strain that arises from attempting to represent diverse groups of citizens on multiple dimensions of political competition. In their recent overview of the topic, Golder and Ferland (2018) highlight studies of mass-elite incongruence as a central branch of the research on representation in contemporary democracies.

Most studies that look at the link between policy preferences and citizen satisfaction have been limited to the general left-right dimension (Curini, Jou, and Memoli 2012; Dahlberg and Holmberg 2014; Mayne and Hakhverdian 2017), leaving the disconnect between parties and voters on other issues as something of a 'blind corner' in the study of representation' (Thomassen 2012). Recently, Stecker and Tausenpfund (2016) shed some light on the previously dark corner of multidimensional incongruence by providing evidence that citizens who were closer to the governments' policy positions, beyond simply left-right, were more satisfied with democracy. So, while Curini, Jou, and Memoli (2012) demonstrates that governmentcitizen left-right incongruence affects citizen satisfaction, Stecker and Tausenpfund (2016) do so for European integration, a dimension that features low levels of responsiveness from mainstream parties (Rohrschneider and Whitefield 2016; Hooghe and Marks 2018).

For our purposes, immigration policy is a key component of the socio-cultural dimension in most European democracies (Rovny and Polk 2019), particularly for populist radical right parties (Ivarsflaten 2008). Scholars highlight immigration and European integration, in particular, as the political topics most closely connected to an emerging cosmopolitan-parochial

divide along an increasingly contested transnational cleavage (De Vries 2018a; Hooghe and Marks 2018). Thus, there is good reason to expect that incongruence levels matter for citizen disaffection, that this question should be addressed from a multi-dimensional perspective in the European context, and that in addition to European integration and economic redistri- 
bution, party-voter incongruence on the immigration issue taps into a central aspect of this relationship.

Many studies of incongruence focus on the relationship between citizens and the government. Instead, we investigate the incongruence levels between the policy positions of mainstream political parties and their voters. We argue it is important that citizens believe that their policy preferences are at least represented by a party with access to parliament to voice those preferences in the legislative debates, whether in or out of government.

For conceptual and practical reasons, we focus on citizen disaffection rather than satisfaction with democracy. Practically, the 2014 EES did not include the standard satisfaction with democracy question. But conceptually, political disaffection entails more dramatic and normatively challenging features than 'mere' dissatisfaction, including 'personal inefficacy, cynicism and distrust, lack of confidence in representative institutions and/or the representatives elected, the belief that political elites do not care about the welfare of their citizens, and a general sense of estrangement from both politics and the political processes' (Torcal and Montero 2006, 5). We assert that this describes the current political moment well for many European (and American) citizens, and that perceived failures of substantive representation can help us understand this disaffection.

With a foundation in Downsian spatial models, we anticipate that citizens prefer parties that minimise the distance between their policy preference and the position of the political party in a multidimensional space, as measured by experts. We also expect that larger distances between a citizen and that citizen's chosen party will be associated with more political disaffection, which leads to the following hypothesis:

Hypothesis 1: The larger the party-voter incongruence, on multiple dimensions and specific issues, the more likely that voter will be politically disaffected.

Our understanding of political disaffection is as a measure of diffuse levels of systemic 
support. It measures the extent to which citizens believe that they themselves are engaged in the political process and that their participation matters for political outcomes. Contemporary research on political disaffection suggests that it is 'commonly expressed as cynicism, resentment and even hatred of democratic institutions and governing elites' and fuels support for populism (Boswell et al. 2019, 8). As highlighted above, mainstream parties of the left and the right have seen their vote shares drop as challenger parties rise on both sides of the ideological spectrum (Hobolt and Tilley 2016). This, in turn, produces substantial interest in the impact that these anti-elite challenger parties have on mainstream parties and general patterns of political competition (Rooduijn, de Lange, and Van Der Brug 2014; Abou-Chadi 2016; Hernández 2018).

In order to speak to the growing interest in citizens turning away from mainstream or establishment parties, we focus our analysis specifically on individuals in the EES that reported voting for a mainstream party in the prior national legislative election. A substantial body of research documents a connection between political discontent and populist voting (e.g. Lubbers, Gijsberts, and Scheepers 2002; Norris 2005; Schumacher and Rooduijn 2013). Our expectation is that even among a group of relatively engaged voters, i.e. non-abstaining, mainstream party supporters, higher levels of disaffection will be associated with higher vote propensity scores for anti-establishment parties. As both a test of our disaffection measure and the expectation that higher levels of disaffection are associated with more support for anti-establishment and populist parties, we formulate the following hypothesis:

Hypothesis 2: The larger the individual political disaffection, the higher the propensity to vote for anti-elite/establishment parties among self-identified mainstream party supporters.

To summarise, we proceed with a two-step investigation of the relationship between partypartisan incongruence, disaffection at the national and European level, and support for antielite parties among mainstream party voters. First, we expect higher levels of incongruence 
to be associated with higher levels of national and EU disaffection. Second, we anticipate that these disaffection measures will be positively correlated with a greater propensity to vote for parties that emphasise anti-elite rhetoric. This second expectation - that the politically disaffected would be more likely to support anti-establishment parties - is quite intuitive, and so this last proposed relationship also serves as something of a validity check for our disaffection measures. But it also shifts the emphasis to voting intentions and behaviour. In the next section of the paper, we explain these measures of disaffection in more detail.

\section{Measuring Individual-level Disaffection}

The 2014 EES voter study did not include a question that directly measures satisfaction with democracy. But Disaffected Democracies emphasises trust in government and efficacy as crucial indicators for disaffection (Putnam, Pharr, and Dalton 2000; Newton and Norris 2000). For the disaffection variables, we therefore turned to 10 questions, pertaining to 5 concepts, that tap into these concepts at both the national and European level. We distinguish between national and European disaffection for several reasons. First, the European Union potentially suffers from a democratic deficit, which suggests the possibility that a disconnect between citizens and politicians at the European level is of particular relevance (Follesdal and Hix 2006). Second, recent evidence points to democratic erosion within some Member States, such as Hungary and Poland, at the national level (Kelemen 2017). Finally, and related, analysis of public opinion in Europe shows substantial country-level variation in satisfaction with democracy at the national and European level (Hobolt 2012, 92). We therefore estimate separate factor models on the national and EU variables to extract two latent variables: EU disaffection and national disaffection. ${ }^{2}$

1. Whether respondent's voice counts in the country/EU

2. Whether respondent trusts their country's parliament/EU institutions

\footnotetext{
${ }^{2}$ We also test one political disaffection variable incorporating both EU and national-level disaffection questions, which yield consistent results. This analysis and the disaffection factor analyses are presented in online appendix C.
} 
3. Whether the respondent would say their country's legislature/European Parliament takes the concerns of citizens into consideration

4. Whether respondent would say that things are going in the right or wrong direction in their country/EU

5. Whether the respondent approves or disapproves of the country's government's record to date/the actions of the EU during the last 12 months

The Cronbach's alpha for the EU disaffection and national disaffection latent variables are 0.79 and 0.80 , respectively, which suggests that our measures tap into a cohesive underlying concept. Again, given the rise of anti-establishment sentiment, a variable that succinctly estimates an individual's political disaffection is an important measure. Figure 1 displays the average values of EU and national disaffection (with 95\% confidence intervals) across European countries for all voters. Greece, Bulgaria, and Romania are the countries with the highest average levels of national disaffection, which should come as little surprise given the hardships of Greece during the great recession, and persistent problems of corruption and state capacity in Romania and Bulgaria (Spendzharova and Vachudova 2012). In contrast, Denmark, Sweden, Netherlands, and Finland have the lowest average levels of national disaffection and are also a group of countries with high quality of government and economies that performed relatively well throughout the recession.

EU disaffection values are similar to national disaffection scores in most countries. Note, for example, the high levels of national and EU disaffection in Spain, Italy, and Portugal, all countries hard-hit by the recession. However, in several member states citizens are more content with the EU than their national political system (e.g., Bulgaria and Romania), whereas the UK displays much higher EU rather than national disaffection, as do (to a lesser extent than the UK) the four Northern member states discussed above. Taken together, these graphs are broadly consistent with de Vries' (2018) benchmarking theory of EU public opinion, suggest substantial variation in our dependent variable across Europe, and offer face validity for the measures.

Within countries, the party families with the highest average levels of political disaffection 


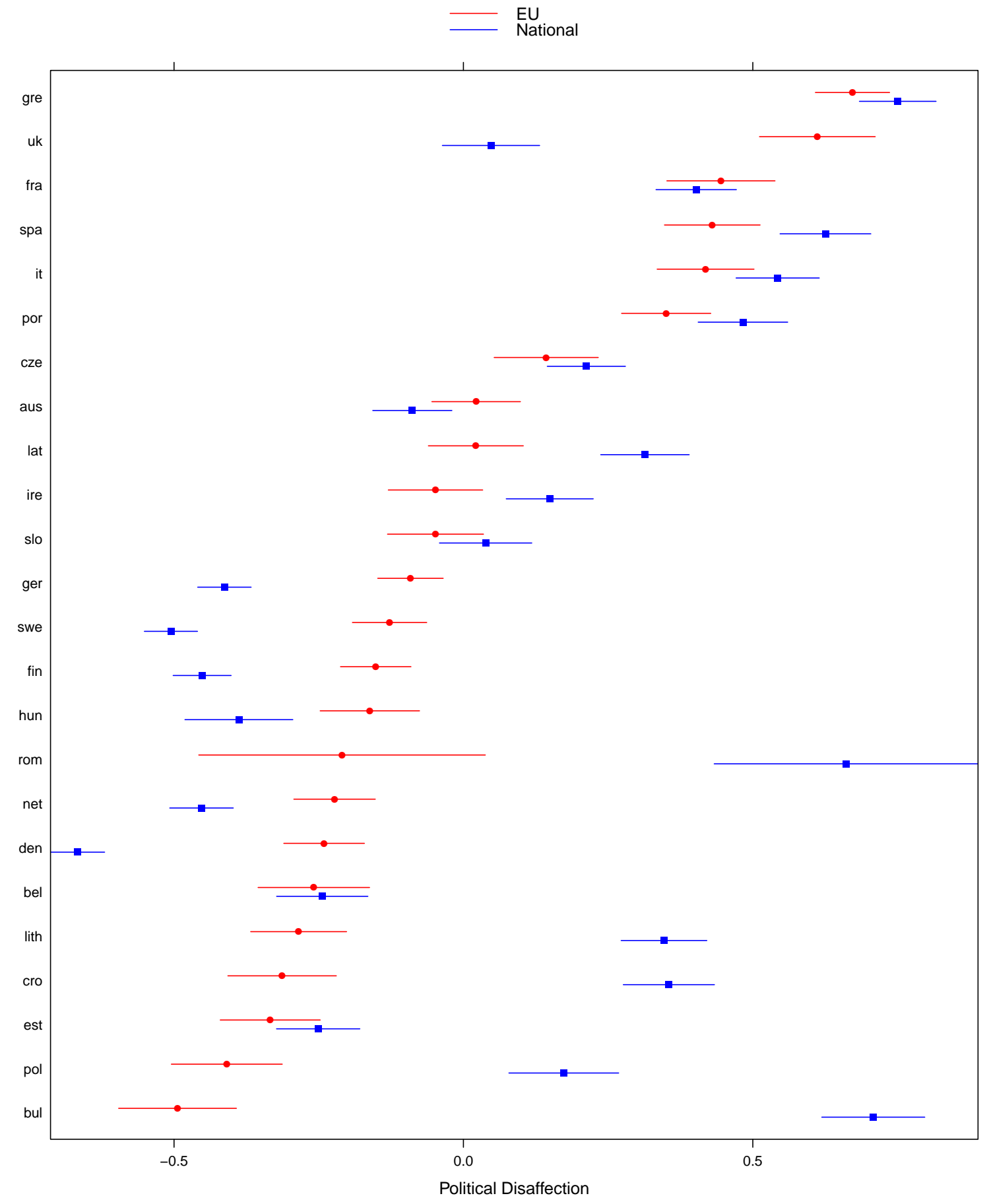

Figure 1: Political disaffection, by country

All voters 
are the radical left and the radical right. The fact that higher average levels of political disaffection are concentrated in the ideological extremes compared to the more centrist party families further indicates that the latent dependent variables capture something close to the concepts they were designed to measure. ${ }^{3}$ In the next section, we conduct analyses of political disaffection.

\section{Analysing Political Disaffection}

Theoretically, we are interested in testing whether party-voter linkages (or lack thereof) affect political disaffection. The CHES and EES teams coordinated their 2014 surveys to ask the same or similar questions across a range of dimensions and issues. This allows researchers to combine estimates of party positions with measures of citizen preferences on the same topic. In addition to the general left-right dimension, it is now possible to generate party-voter incongruence scores for immigration, redistribution, the trade-off between taxing and spending, the role of government in the economy, civil liberties vs. law and order, and environmental policy. ${ }^{4}$ Again, here we focus on the general left-right and the three key issues in 2014: immigration, EU, and economic left-right (proxied by redistribution). ${ }^{5}$

In order to construct individual-level incongruence scores on these issues, we take the absolute value of the distance between the position of the party (taken from CHES) and the position of that party's voters on the issue (taken from EES) (Bakker, Jolly, and Polk 2018). A party's voters are defined as individuals that reported voting for the party in the previous national election, and those EES respondents that did not vote in the previous election are

\footnotetext{
${ }^{3}$ It is also interesting to note that national disaffection levels are higher than European disaffection for regionalist parties, which is consistent with the argument that regionalist parties see the EU as a means of advancing their viability vis-à-vis national politics (Jolly 2015).

${ }^{4}$ The questions wordings for the CHES and EES surveys are available in online appendix A.

${ }^{5}$ In online appendix D, we include all measures of incongruence included in CHES and EES. The EU budgets question has similar effects to the EU position question, while the civil liberties question is significant only in the national disaffection model, similar to redistribution. The main results are robust in these alternative specifications.
} 
not included in the analysis. ${ }^{6}$ The smaller this distance, the lower the incongruence level. ${ }^{7}$ We use an external measure of party positions rather than individual placements of the party because citizen-based measures of party positions on multiple dimensions are limited, and expert and citizen-based measures of left-right are highly correlated (Rohrschneider and Whitefield 2012; Bakker et al. 2015). ${ }^{8}$

To test Hypothesis 1, we utilise incongruence on left-right, redistribution, EU, and immigration, which are associated with the general left-right and three dimensions (of varying interrelation) in the CHES data (Bakker, Jolly, and Polk 2012). As outlined in Hypothesis 1, we expect that greater levels of incongruence will be associated with greater levels of political disaffection and we test this specifically for voters who supported mainstream parties. For controls, we follow the satisfaction with democracy literature and include measures of respondents' age, education, partisanship, evaluation of the economy, gender, and political knowledge (Norris 1999; Hobolt and Spoon 2012; Dahlberg, Linde, and Holmberg 2015; Stecker and Tausenpfund 2016). Typically, this research builds on three schools of thought related to political trust: socio-psychological (some individuals are less trusting in general); social and cultural (trust depends on socialisation and social capital); and institutional performance (individuals trust better performing governments) (Newton and Norris 2000).

Due to the hierarchical nature of these data, we estimate separate mixed effect models with country random effects for each type of disaffection. This helps us indirectly control for variation in institutional performance across countries highlighted by the third school of thought in the preceding paragraph, in addition to other national-level variables like timing

\footnotetext{
${ }^{6}$ If anything, this decision should make it harder to find effects of incongruence since abstaining voters should be among the most incongruent. Since national elections take place at different times in relation to the EES survey, we conducted separate analysis using months since last election as a control and splitting the countries into three sub-samples (furthest from national election to closest). Online Appendix G presents the results using the months control and find robust results for the variables of interest.

${ }^{7}$ It is important to note that our absolute measure of incongruence only takes into consideration the magnitude of the incongruence, not its direction.

${ }^{8}$ In online appendix F, we investigate incongruence based on the respondent's party placement. The correlation between general left-right incongruence based on CHES and EES is 0.87. After controlling for the missingness associated with respondent-based party positions, the key results are robust.
} 
of elections. In these models, incongruence on the three specific issues (immigration, EU, and redistribution) is statistically significant and associated with higher levels of national or EU political disaffection, whereas general left-right incongruence is insignificant.

Table 1: Mixed Effects Regression of EU and National Disaffection (Mainstream Voters)

(1)

(2)

EU Disaffection National Disaffection

\begin{tabular}{|c|c|c|}
\hline \multicolumn{3}{|l|}{ Main } \\
\hline Left-Right Incongruence & $\begin{array}{c}-0.01 \\
(0.01)\end{array}$ & $\begin{array}{c}0.00 \\
(0.01)\end{array}$ \\
\hline EU Incongruence & $\begin{array}{l}0.08^{* * *} \\
(0.00)\end{array}$ & $\begin{array}{l}0.03^{* * *} \\
(0.00)\end{array}$ \\
\hline Immigration Incongruence & $\begin{array}{l}0.02^{* *} \\
(0.01)\end{array}$ & $\begin{array}{l}0.02^{* * *} \\
(0.00)\end{array}$ \\
\hline Redistribution Incong & $\begin{array}{c}0.01 \\
(0.01)\end{array}$ & $\begin{array}{l}0.02^{* * *} \\
(0.00)\end{array}$ \\
\hline Male & $\begin{array}{l}0.07^{* * *} \\
(0.02)\end{array}$ & $\begin{array}{c}-0.02 \\
(0.02)\end{array}$ \\
\hline Age & $\begin{array}{c}-0.00 \\
(0.00)\end{array}$ & $\begin{array}{c}-0.00^{* * *} \\
(0.00)\end{array}$ \\
\hline Education & $\begin{array}{c}-0.06^{* * *} \\
(0.01)\end{array}$ & $\begin{array}{c}-0.04^{* *} \\
(0.01)\end{array}$ \\
\hline Political Knowledge & $\begin{array}{l}0.05^{* * *} \\
(0.01)\end{array}$ & $\begin{array}{c}0.01 \\
(0.01)\end{array}$ \\
\hline Prospective Economic & $\begin{array}{c}-0.20^{* * *} \\
(0.01)\end{array}$ & $\begin{array}{c}-0.23^{* * *} \\
(0.01)\end{array}$ \\
\hline Economic Retrospective & $\begin{array}{c}-0.10^{* * *} \\
(0.01)\end{array}$ & $\begin{array}{c}-0.19^{* * *} \\
(0.01)\end{array}$ \\
\hline Political Interest & $\begin{array}{c}-0.16^{* * *} \\
(0.01)\end{array}$ & $\begin{array}{c}-0.10^{* * *} \\
(0.01)\end{array}$ \\
\hline Partisanship & $\begin{array}{c}-0.03^{* *} \\
(0.01)\end{array}$ & $\begin{array}{c}-0.03^{* * *} \\
(0.01)\end{array}$ \\
\hline Constant & $\begin{array}{l}0.93^{* * *} \\
(0.10)\end{array}$ & $\begin{array}{l}1.64^{* * *} \\
(0.09)\end{array}$ \\
\hline$\overline{\mathrm{AIC}}$ & 13763.18 & 15665.68 \\
\hline BIC & 13864.33 & 15769.65 \\
\hline $\mathrm{SD}$ of $\mathrm{RE}$ & 0.29 & 0.28 \\
\hline Rho & 0.14 & 0.15 \\
\hline $\mathrm{N}$ & 6271 & 7564 \\
\hline
\end{tabular}

${ }^{*} p<0.05,{ }^{* *} p<0.01,{ }^{* * *} p<0.001$

Random effects regression (group variable: country) with standard errors in parentheses.

Rho is the fraction of variance due to country. 
Importantly, higher levels of the three specific incongruence measures are associated with more national disaffection, and EU and immigration incongruence are associated with more EU disaffection. But there are interesting differences among the issue-specific incongruence measures, namely that the effect of party-voter EU incongruence, while statistically significant for both, is nearly two times larger for EU disaffection than national disaffection. In contrast, redistribution incongruence is significant for national disaffection but not for EU disaffection.

The specific incongruence measures are significant, but general left-right incongruence does not have an effect. ${ }^{9}$ As discussed earlier, mainstream parties tend to have much better congruence with their voters on general left-right, and there is less variation on this measure than the others. These results highlight the importance of looking beyond the general left-right dimension when analyzing party-voter representational relationships in European democracies. Further, while the effect of EU incongruence is unsurprisingly larger for the measure of EU disaffection, its significance in the national disaffection model points to the domestic contestation of the European Union (JEPP Special Issue 2019).

Summarizing, higher levels of the three issue-specific incongruence measures are associated with more political disaffection at the national and European level, while EU incongruence matters more than the other incongruence measures for EU disaffection. Of course, misrepresentation is just one factor among many that explains disaffection and dissatisfaction, but it is a factor that has been under-studied. In addition, the incongruence coefficients should be looked at in tandem with the strong set of controls included in these models, such as a respondent's attitude about the performance of the economy, political interest, education, and partisanship. On the whole, we interpret the findings of Table 1 to be consistent with the expectation we advanced in our first hypothesis. In the next section of the paper, we investigate whether the two measures of disaffection matter for voting behaviour. Again, while disaffection is interesting on its own, we seek to understand the relationship between

\footnotetext{
${ }^{9}$ In sensitivity analysis, we evaluated the effect of only general left-right incongruence and the controls in the models and the effects are still insignificant. These results are presented in online appendix E.
} 
these attitudes and behaviour, especially support for anti-elite parties.

\section{Propensity to Vote for Anti-Elite Parties}

Defining and measuring populism is a particularly robust and sometimes contentious subfield of comparative politics (see, e.g., Aslanidis (2016); Bonikowski and Gidron (2016); Mudde and Rovira Kaltwasser (2018)). And although important definitional divisions exist between populism scholars, there is rather broad agreement that populism is not exclusive to the political left or right, and that populist parties position themselves against the political establishment, championing 'the people' rather than 'the elite' (Mudde 2004, 2007; March 2007; Otjes and Louwerse 2015). Taking this broader theoretical discussion surrounding the appropriate definition of populism into account, we focus more narrowly on the antielite/establishment component, a feature that is recognized as a necessary (although not always sufficient) aspect of all populist parties.

The CHES data allow us to separate parties in Europe according to the salience that they attribute to anti-elite, anti-establishment rhetoric (0 (Not At All Important) to 10 (Very Important)). We choose 7.0 as the cutpoint, with any party at or above this value defined as an anti-establishment party in the subsequent analysis. ${ }^{10}$ Our dependent variable in this section is taken from the EES propensity to vote (PTV) measures (Van der Eijk et al. 2006). Compared to a respondent's recalled vote choice, the standard dependent variable in most voting models, PTV scores are particularly useful for our analysis because they allow a survey respondent to indicate their willingness to consider voting for a larger range of the parties in a country. This allows us to track the PTV for anti-elite parties among all survey respondents rather than just those individuals that reported voting for these parties. ${ }^{11}$

\footnotetext{
${ }^{10}$ The primary results reported below are robust to alternate thresholds for categorising anti-elite parties. These include designating all parties more than one standard deviation above the mean as anti-elite, and choosing thresholds of 6 or 8 instead of 7 . Online appendix $\mathrm{H}$ includes the list of parties included.

${ }^{11}$ If there are multiple anti-elite parties in a country, we take the maximum PTV score. Given our interest in what factors drive mainstream voters towards the extreme parties, we assert that the anti-elite party with the largest PTV is the appropriate choice.
} 
Due to the hierarchical nature of these data, we utilize mixed effect models with country random effects. ${ }^{12}$ These random effects allow us to focus on the theoretically interesting variables, while controlling for obvious differences across different regions of Europe. We present the results of this analysis in Table 2, which supports our expectation that political disaffection increases the willingness of mainstream party supporters to consider voting for anti-elite/establishment parties. As above, we separated our measure of disaffection into distinct national and European components.

\footnotetext{
${ }^{12}$ The logic of the proposed relationship (Incongruence to Disaffection to PTVs) is intuitively a path model, with both direct and indirect (via disaffection) paths from incongruence to PTVs. This path model is presented in the online appendix B. Though we present the simpler, separate models in the text, we also investigated a structural equation model, and find comparable substantive effects. The full structural equation model is available upon request.
} 
Table 2: Regression on Propensity to Vote for Populist Parties (Mainstream Voters)

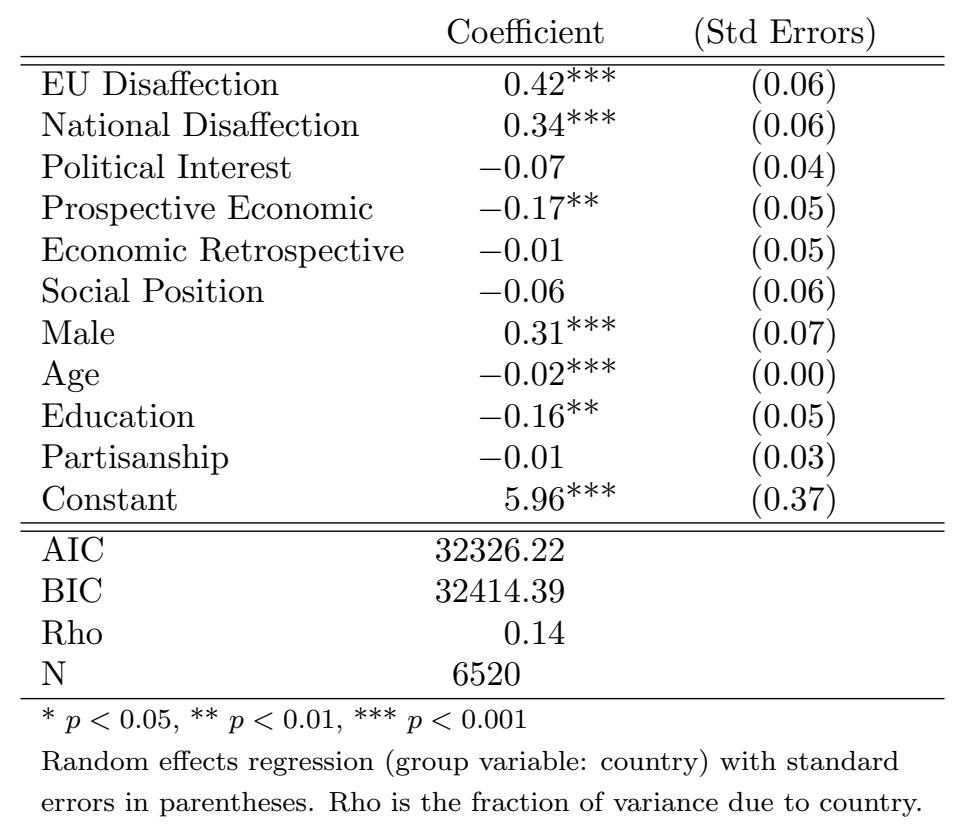
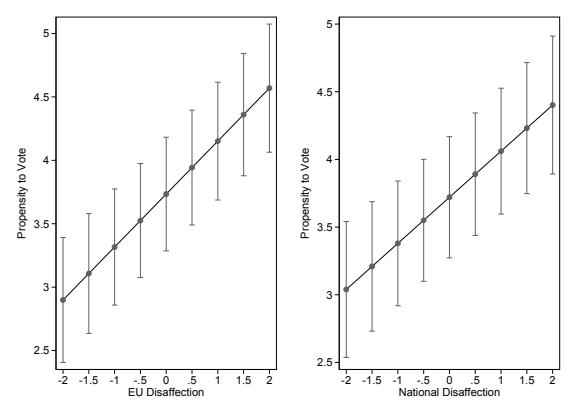

Figure 2: Marginal Effects Plot for the effect of disaffection on PTV for Anti-Elite parties, Mainstream Voters 
As is clear in Table 2 and Figure 2, both European and national political disaffection factors are associated with an increased propensity to vote for anti-elite parties, even in the presence of a strong set of controls. That these controls perform as expected generates additional confidence in the analysis: individuals with less optimism about the future of the economy's performance, men, younger people, and those with less education are all statistically associated with higher PTVs for anti-elite/establishment parties. Self-reported political interest, retrospective views of the economy, partisanship, and self-reported position in society are not statistically significant in this model.

As discussed above, our finding that the politically disaffected are more likely to consider voting for an anti-establishment party should not be surprising. Nevertheless, it supports the broader argument of this paper in at least three ways. First, the fact that the disaffection measures are associated with increased PTVs for anti-system parties, as expected, provides a degree of empirical validation for the latent disaffection measures. The disaffected should be more inclined to support such parties, and it increases our confidence in the measure to find a strong relationship between the two.

Second, the analysis only includes individuals that reported voting for a mainstream party in the previous national election. Excluding citizens that either abstained or already voted for anti-system parties helps us isolate the effect of disaffection on the voter group that should be most resistant to populist appeals. Even among mainstream voters, political disaffection is a powerful factor in leading voters to consider supporting anti-establishment parties, which has substantial normative ramifications. Although some studies report that these parties provide an important means of addressing political discontent within the political system and therefore stabilise more general system-level support (Miller and Listhaug 1990), there is growing evidence that voting for anti-elite parties actually increases political discontent and extremism in policy preferences, thereby undermining support for the political system (Rooduijn, Van Der Brug, and De Lange 2016; Harteveld, Kokkonen, and Dahlberg 2017; Hooghe and Dassonneville 2018). From the perspective of mainstream parties, this implies 
that once these voters are lost to anti-system challenger parties, they will be difficult to win back.

Finally, the disaggregation of the disaffection measure into national and EU components helps us understand how contestation of Europe affects domestic electoral politics. The measure of political disaffection at the European level exerts a strong impact on an individual's PTV for an anti-system party as does national disaffection. This provides support for the idea that domestic contestation of the European Union is taking place. Disaffection at the EU level is associated with an increased willingness to consider voting for anti-systemic parties. These analyses, therefore, offer evidence of a clear link between (mis)representation, disaffection, and support for anti-elite parties.

\section{Discussion}

Across Europe, mainstream parties of all ideological stripes have lost electoral support (Hobolt and Tilley 2016). In France and the Netherlands, former leftist government parties have seen their vote shares drop to existentially low levels. Our departure point in this paper is the intuition that this substantial electoral shift away from established political parties is connected to political disaffection among voters.

Mainstream parties of Western Europe have not been particularly responsive to voter preferences on the EU (Rohrschneider and Whitefield 2016; Hooghe and Marks 2018). Further, the resulting mass-elite incongruence on issues beyond general left-right ideology, particularly the EU, negatively affect citizen satisfaction with democracy (Stecker and Tausenpfund 2016), and recent experimental evidence indicates that input-oriented legitimacy remains an important aspect of democratic governance in European societies (Strebel, Kübler, and Marcinkowski 2018). Our analysis is consistent with these findings, and extends them in several ways.

Our findings that incongruence on the EU, redistribution, and immigration each has an 
effect on disaffection corroborate other studies that highlight the challenges for parties trying to represent the interests of voters on multiple dimensions (Hobolt and Rodon 2019). EU incongruence appears to exert an impact on both European and domestic politics. Citizenelite incongruence on this dimension varies widely across the EU (Bakker, Jolly, and Polk 2018), which makes it all the more essential that scholars have begun to map and explain this variation (Goldberg, van Elsas, and de Vreese 2019). More generally, our paper supports the argument that the socio-cultural and EU positions of mainstream parties can affect their electoral support (Abou-Chadi and Wagner 2019).

We have presented evidence that party-partisan incongruence is associated with political disaffection at the national and European level, and that this disaffection is in turn associated with a greater propensity to support anti-elite/establishment parties across European democracies. But of course much work remains to better understand these relationships. Future analyses will hopefully be able to build from panel survey data to better model the causal relationship between incongruence, disaffection, and anti-establishment party support. Further, new studies should test for moderators of these effects, such as political interest or salience (Stecker and Tausenpfund 2016), along with contextual variables. The latter will be particularly important given the evidence that not only policy but also priority incongruence matters for citizen satisfaction (Reher 2016). And although the present research is by no means the final word on the matter, we have argued that the crisis for mainstream parties can be at least partially attributed to a break in the party-voter linkage crucial to democracy, a break with increasingly deep consequences. 


\section{References}

Abou-Chadi, Tarik. 2016. "Niche party success and mainstream party policy shifts-how green and radical right parties differ in their impact." British Journal of Political Science $46(2)$ : $417-436$.

Abou-Chadi, Tarik and Markus Wagner. 2019. "Electoral Fortunes of Social Democratic Parties: Do Second Dimension Positions matter?" JEPP .

Aslanidis, Paris. 2016. "Is populism an ideology? A refutation and a new perspective." Political Studies 64 (1S): 88-104.

Bakker, Ryan, Catherine De Vries, Erica Edwards, Liesbet Hooghe, Seth Jolly, Gary Marks, Jonathan Polk, Jan Rovny, Marco Steenbergen, and Milada Anna Vachudova. 2015. "Measuring party positions in Europe The Chapel Hill expert survey trend file, 1999-2010." Party Politics 21.1: 143-152.

Bakker, Ryan, Seth Jolly, and Jonathan Polk. 2012. "Complexity in the European Party Space: Exploring Dimensionality with Experts." European Union Politics 13.2: 219-245.

Bakker, Ryan, Seth Jolly, and Jonathan Polk. 2018. "Multidimensional Incongruence and Vote Switching in Europe." Public Choice 176 (1-2): 267-296.

Bonikowski, Bart and Noam Gidron. 2016. "Multiple Traditions in Populism Research: Toward a Theoretical Synthesis." APSA Comparative Politics Newsletter 26 (2): 7-14.

Boswell, John, Jack Corbett, Kate Dommett, Will Jennings, Matthew Flinders, RAW Rhodes, and Matthew Wood. 2019. "State of the field: What can political ethnography tell us about anti-politics and democratic disaffection?" European Journal of Political Research 58 (1): 56-71.

Bulfone, Fabio and Manès Weisskircher. 2018. "What Italy's Economic Woes Mean for Sunday's Vote." Washington Post Monkey Cage blog. 1 March https://wapo.st/2E7SLOr. Last accessed: 30 March 2018.

Curini, Luigi, Willy Jou, and Vincenzo Memoli. 2012. "Satisfaction with democracy and the winner/loser debate: The role of policy preferences and past experience." British Journal of Political Science 42 (2): 241-261.

Dahlberg, Stefan, Jonas Linde, and Sören Holmberg. 2015. "Democratic discontent in old and new democracies: Assessing the importance of democratic input and governmental output." Political Studies 63 (1_suppl): 18-37.

Dahlberg, Stefan and Sören Holmberg. 2014. "Democracy and bureaucracy: How their quality matters for popular satisfaction." West European Politics 37 (3): 515-537.

De Vries, Catherine E. 2018a. "The cosmopolitan-parochial divide: changing patterns of party and electoral competition in the Netherlands and beyond." Journal of European Public Policy 25 (11): 1541-1565. 
De Vries, Catherine E. 2018b. Euroscepticism and the Future of European Integration. Oxford University Press.

Follesdal, Andreas and Simon Hix. 2006. "Why there is a democratic deficit in the EU: A response to Majone and Moravcsik." JCMS: Journal of Common Market Studies 44 (3): $533-562$.

Foster, Chase and Jeffry Frieden. 2017. "Crisis of trust: Socio-economic determinants of Europeans' confidence in government." European Union Politics 18 (4): 511-535.

Goldberg, Andreas C., Erika J. van Elsas, and Claes H. de Vreese. 2019. "Mismatch? The differential discrepancy between elites' and citizens' EU attitudes across four countries." JEPP .

Golder, Matt and Benjamin Ferland. 2018. "Electoral Rules and Citizen-Elite Ideological Congruence." In The Oxford Handbook of Electoral Systems, ed. Erik S. Herron, Robert J. Pekkanen, and Matthew S. Shugart. Oxford: Oxford University Press.

Harteveld, Eelco, Andrej Kokkonen, and Stefan Dahlberg. 2017. "Adapting to party lines: the effect of party affiliation on attitudes to immigration." West European Politics 40 (6): $1177-1197$.

Hernández, Enrique. 2018. "Democratic discontent and support for mainstream and challenger parties: Democratic protest voting." European Union Politics 19 (3): 458-480.

Hobolt, Sara B. 2012. "Citizen satisfaction with democracy in the European Union." JCMS: Journal of Common Market Studies 50 (s1): 88-105.

Hobolt, Sara B. 2018. "Brexit and the 2017 UK General Election." JCMS: Journal of Common Market Studies .

Hobolt, Sara B. and Jae-Jae Spoon. 2012. "Motivating the European voter: Parties, issues and campaigns in European Parliament elections." European Journal of Political Research 51.6: $701-727$.

Hobolt, Sara B. and James Tilley. 2016. "Fleeing the Centre: The Rise of Challenger Parties in the Aftermath of the Euro Crisis." West European Politics 39.5: 971-991.

Hobolt, Sara B. and Toni Rodon. 2019. "Cross-cutting issues and electoral choice. EU issuevoting in the aftermath of Brexit." JEPP.

Hooghe, Liesbet and Gary Marks. 2003. "Unraveling the central state, but how? Types of multi-level governance." American Political Science Review 97 (2): 233-243.

Hooghe, Liesbet and Gary Marks. 2018. "Cleavage theory meets Europe's crises: Lipset, Rokkan, and the transnational cleavage." Journal of European Public Policy 25 (1): 109135. 
Hooghe, Marc and Ruth Dassonneville. 2018. "A spiral of distrust: A panel study on the relation between political distrust and protest voting in Belgium." Government and Opposition 53 (1): 104-130.

Inglehart, Ronald. 1988. "The Renaissance of Political Culture." American Political Science Review 82.4: 1203-1230.

Ivarsflaten, Elisabeth. 2008. "What unites right-wing populists in Western Europe? Reexamining grievance mobilization models in seven successful cases." Comparative Political Studies 41 (1): 3-23.

Jolly, Seth K. 2015. The European Union and the rise of regionalist parties. University of Michigan Press.

Kelemen, R Daniel. 2017. "Europe's other democratic deficit: National authoritarianism in Europe's Democratic Union." Government and opposition 52 (2): 211-238.

Lubbers, Marcel, Mérove Gijsberts, and Peer Scheepers. 2002. "Extreme right-wing voting in Western Europe." European Journal of Political Research 41 (3): 345-378.

Magalhães, Pedro C. 2005. "Disaffected democrats: Political attitudes and political action in Portugal." West European Politics 28 (5): 973-991.

March, Luke. 2007. "From vanguard of the proletariat to vox populi: Left-populism as a'shadow'of contemporary socialism." SAIS Review 27 (1): 63-77.

Mayne, Quinton and Armen Hakhverdian. 2017. "Ideological congruence and citizen satisfaction: Evidence from 25 advanced democracies." Comparative Political Studies 50 (6): 822-849.

Miller, Arthur H and Ola Listhaug. 1990. "Political parties and confidence in government: A comparison of Norway, Sweden and the United States." British Journal of Political Science 20 (3): 357-386.

Mudde, Cas. 2004. "The populist zeitgeist." Government and opposition 39 (4): 542-563.

Mudde, Cas. 2007. Populist radical right parties in Europe. Cambridge University Press Cambridge.

Mudde, Cas and Cristóbal Rovira Kaltwasser. 2018. "Studying Populism in Comparative Perspective: Reflections on the Contemporary and Future Research Agenda." Comparative Political Studies , 0010414018789490.

Newton, Kenneth and Pippa Norris. 2000. "Confidence in Public Institutions: Faith, Culture, or Performance?" In Disaffected Democracies. What's Troubling the Trilateral Democracies?, ed. Susan J. Pharr and Robert D. Putnam. Princeton, NJ: Princeton University Press, 52-73.

Norris, Pippa. 1999. Critical citizens: Global support for democratic government. OUP Oxford. 
Norris, Pippa. 2005. Radical right: Voters and parties in the electoral market. Cambridge University Press.

Otjes, Simon and Tom Louwerse. 2015. "Populists in Parliament: Comparing Left-Wing and Right-Wing Populism in the Netherlands." Political Studies 63 (1): 60-79.

Polk, Jonathan, Jan Rovny, Ryan Bakker, Erica Edwards, Liesbet Hooghe, Seth Jolly, Jelle Koedam, Filip Kostelka, Gary Marks, Gijs Schumacher, Marco Steenbergen, Milada Vachudova, and Marko Zilovic. 2017. "Explaining the salience of anti-elitism and reducing political corruption for political parties in Europe with the 2014 Chapel Hill Expert Survey data." Research $\&$ Politics 4.1 (January-March): 1-9.

Putnam, Robert D., Susan J. Pharr, and Russell J. Dalton. 2000. "Introduction: What's Troubling the Trilateral Democracies?" In Disaffected Democracies. What's Troubling the Trilateral Democracies?, ed. Susan J. Pharr and Robert D. Putnam. Princeton, NJ: Princeton University Press, 3-30.

Reher, Stefanie. 2016. "The Effects of Congruence in Policy Priorities on Satisfaction with Democracy." Journal of Elections, Public Opinion and Parties 26 (1): 40-57.

Rohrschneider, Robert and Stephen Whitefield. 2012. The Strain of Representation: How Parties Represent Diverse Voters in Western and Eastern Europe. Oxford: Oxford University Press.

Rohrschneider, Robert and Stephen Whitefield. 2016. "Responding to growing European Union-skepticism? The stances of political parties toward European integration in Western and Eastern Europe following the financial crisis." European Union Politics 17.1 (March): $138-161$.

Rooduijn, Matthijs, Sarah L de Lange, and Wouter Van Der Brug. 2014. "A populist Zeitgeist? Programmatic contagion by populist parties in Western Europe." Party Politics 20 (4): 563-575.

Rooduijn, Matthijs, Wouter Van Der Brug, and Sarah L De Lange. 2016. "Expressing or fuelling discontent? The relationship between populist voting and political discontent." Electoral Studies 43: 32-40.

Rovny, Jan and Jonathan Polk. 2019. "New wine in old bottles: explaining the dimensional structure of European party systems." Party Politics 25 (1): 12-24.

Schmitt, Hermann, Sebastian A. Popa, Sara B. Hobolt, and Eftichia Teperoglou. 2015. "European Parliament Election Study 2014, Voter Study." GESIS Data Archive, Cologne. ZA5160 Data file Version 2.0.0.

Schumacher, Gijs and Matthijs Rooduijn. 2013. "Sympathy for the 'devil'? Voting for populists in the 2006 and 2010 Dutch general elections." Electoral Studies 32 (1): 124133. 
Spendzharova, Aneta B and Milada Anna Vachudova. 2012. "Catching up? Consolidating liberal democracy in Bulgaria and Romania after EU accession." West European Politics 35 (1): $39-58$.

Stecker, Christian and Markus Tausenpfund. 2016. "Multidimensional government-citizen congruence and satisfaction with democracy." European Journal of Political Research 55.3 (August): 492-511.

Strebel, Michael Andrea, Daniel Kübler, and Frank Marcinkowski. 2018. "The importance of input and output legitimacy in democratic governance: Evidence from a populationbased survey experiment in four West European countries." European Journal of Political Research .

Thomassen, Jacques. 2012. "The blind corner of political representation." Representation 48.1: $13-27$.

Torcal, Mariano and José Ramón Montero. 2006. Political disaffection in contemporary democracies: social capital, institutions and politics. Routledge.

Van der Eijk, Cees, Wouter Van der Brug, Martin Kroh, and Mark Franklin. 2006. "Rethinking the dependent variable in voting behavior: On the measurement and analysis of electoral utilities." Electoral Studies 25 (3): 424-447. 